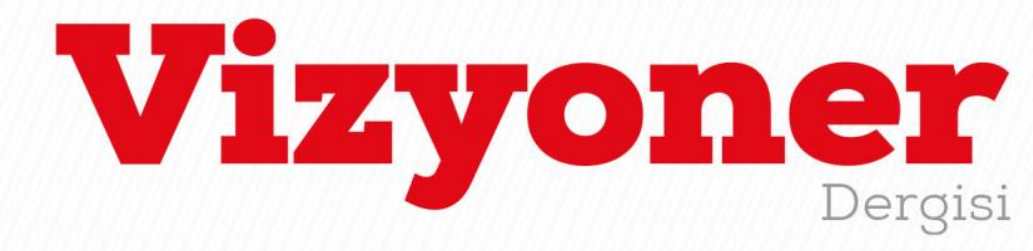

Süleyman Demirel Üniversitesi Vizyoner Dergisi, Yıl: 2021, Cilt: 12, Sayı: 31, 701-711.

Süleyman Demirel University Visionary Journal, Year: 2021, Volume: 12, No: 31, 701-711.

\title{
GET DIGITAL OR GET LOST! A STUDY ON THE DIGITALIZING BUSINESS WORLD AND COVID-19 PANDEMIC
}

\section{DİJITALLEŞ YOKSA YOK OL! COVID-19 PANDEMI SÜRECI VE DİJITTALLEŞEN IŞ DÜNYASI ÜZERINE BİR ÇALIŞMA}

\author{
Assoc. Prof. Dr. Zekiye TAMER GENCER ${ }^{1}$
}

\begin{abstract}
The most recent one called COVID-19 broke out in December, 2019 in Wuhan, China and has still been troubling the countries on the world. The impacts of the pandemic have shown not only on death tolls but also on social, economic and cultural aspects. The global economic crisis stemmed from the epidemic in almost every country has paralyzed everyday life circumstances from health to education and politics. In the study, the business world which is affected by the pandemic is examined in detail. The study especially takes the projects financed and suggested by the Union of Chambers and Commodity Exchanges of Turkey for women entrepreneurs as sample. As an obligation these days, digitalizing has become the trendiest topic in business world. Because of lock downs and social distancing precautions, 8 projects that are suggested by the Union of Chambers and Commodity Exchanges of Turkey have started to be conducted on digital platforms by the entrepreneurs, especially woman entrepreneurs. The digitalizing process of these projects is the main purpose of the study and as the digitalization is getting more and more important day by day, it is a crucial subject to study on as well.
\end{abstract}

Keywords: Economy, Digitalization, COVID-19, Projects for Entrepreneurship, Woman Entrepreneurs.

JEL Classification Codes: M13, M14, M21.

ÖZ

İnsanlık tarihi boyunca görülen kaynağı belli ya da belirsiz birçok salgın hastalığa bir yenisinin eklendiği Covid-19 süreci tüm dünyayı olumsuz etkilemektedir. Bu etkiler hastalığa bağlı can kayıpları başta olmak üzere, sosyal, kültürel ve ekonomik anlamda ciddi bir biçimde kendisini göstermektedir. Tüm dünya ülkelerinin nerdeyse eş zamanlı yaşamaya başladığı salgın hastalığa bağlı olarak yaşanan küresel ekonomik kriz, sağlıktan eğitime, siyasete kadar tüm yaşamsal döngüleri felç etmiştir. $\mathrm{Bu}$ çalışmada, yaşanan bu olumsuz etkilere bağlı olarak iş kaybına uğrayan ticari dünya mercek altına alınmıştır. Türkiye Odalar ve Borsalar Birliği tarafından pandeminin başından beri alınan önlemler, iş dünyasını rahatlatmak adına önerilen projeler ve özellikle de pozitif ayrımcılık yapılarak kadın girişimcilere yönelik olarak yapılan bir takım faaliyetler incelenmiştir. Bu salgın döneminin en büyük zorunluluklarından biri olan dijitalleşme süreci, salgından korunmak için alınan sokağa çıkma yasakları ve sosyal mesafe gibi önlemlere bağlı olarak gerçekleşmiştir. Bu bağlamda TOBB tarafindan yapılan, girişimcileri özellikle de kadın girişimcileri dijital ortama yönlendirmeyi amaçlayan 8 proje çalışma kapsamında analiz edilmiştir.

Anahtar Kelimeler: Ekonomi, Dijitalleşme, COVID-19 Salgını, Girişimcilik Projeleri, Kadın Girişimciler.

JEL Sınıflandırma Kodları: M13, M14, M21.

(D) Sivas Cumhuriyet University, Faculty of Communication, Department of Public Relations and Publicity, zekiye_tamer@hotmail.com Makale Geliş Tarihi / Received : 04.03 .2021

Makale Kabul Tarihi / Accepted $\quad: 30.07 .2021$ 


\section{GENIŞLETILMIŞ ÖZET}

\section{Amaç ve Kapsam:}

Bu çalışma dijitalleşen dünya şartlarında, yeni Covid-19 salgının ekonomi üzerinde yarattığı baskı neticesinde iş yapma biçimlerinin sanal ortamlara taşınması hususundaki mecburiyete dikkat çekmeye çalışmaktadır. Nerdeyse son 15 yıldır insan hayatına yöne vere sosyal ağlar ve internet teknolojiler, pandemi sürecinde yaşanan kısıtlamalara bağlı olarak ticaretin de bu alana entegrasyonunun artırılmasını gerekli kılmıştır. Türkiye de ticaret ve ekonomi alanında önemli bir sivil toplum kuruluşu olan Odalar ve Borsalar Birliğinin bu hususlarda yaptığı çalışmalar ve projeler üzerinden, iş dünyasının dijitalleşme mecburiyeti ortaya konmaktadır.

\section{Yöntem:}

Bu çalışma kapsamında dünya genelinde özellikle ekonomik anlamda olumsuz neticeleri sebebiyle insan hayatını olumsuz etkileyen ve küresel kriz ortamında birçok işletmenin ticari süreçlerini sekteye uğratan Covid-19 salgınının dijitalleşmeyi teşvik etmesi için yapılan projeler değerlendirilmiştir. Bu değerlendirme için de nitel araştırma tekniklerinden biri olan, içerik analizi yöntemi kullanılmıştır. Türkiye Odalar ve Borsalar Birliği tarafından yürütülen 8 adet proje "kim, nasıl, kime, ne zaman, ne, nasıl söylemiştir" sorularından bazılarına cevap aramak için yapılan içerik analizi yöntemi ile değerlendirilmiştir. İçerik analizi yöntemlerinden biri olan değerlendirici analiz şeklinde kurgulanan araştırma, salgın sürecine ekonomik zorluklardan biri olan iş yerlerinin kapatılmasıyla dijital ortamlara geçiş başta olmak üzere rutin işlerin dijital üzerinden de yapılabileceği kanıtlarına dayanan projelerin amaç, hedef kitle ve çıktıları üzerinden bir çerçeve sunmaktır. Özellikle de kadın girişimciler açısından önem arz eden bu projeler kapsamında e- ticarete dönüşüm sağlanması, pandemi sürecinin önemli mücadele araçlarından biri olduğunda, çalışma bu haliyle literatüre önemli bir katkı sunmaktadır.

\section{Bulgular:}

Türkiye Odalar ve Borsalar Birliği tarafından alınan bilgiler ışığında, Kadın Girişimciler Kurulu'nun kontenjanı her ilde, Oda ve Borsa'nın meclis üyesi sayısı ile sınırlı olduğu bilinmektedir. Dolayısı ile yaklașı 7.000 kadın girișimci üyesi olmasına rağmen bu sayı Türkiye genel profilini yansıtmamaktadır. Yapılan araştırma inceleme sonucunda kurum tarafından özellikle kadın girişimciler başta olmak üzere ülkede bulunan tüm kadınların dijital uyumlarının artırılması, gelişimlerine destek olunması gibi bir takım amaçlarla düzenlenen çok sayıda proje olduğu tespit edilmiştir. Bu projelere ilişkin içerik analizi çalıșmada tablo olarak yer almaktadır. Tabloda proje hedef kitlesi, amacı ve çıktılar șeklinde üç boyutlu bir değerlendirme yapılmıştır. Yapılan değerlendirme sonucunda da aşağıdaki tabloda görüldüğü gibi, ilgili projelerin amacına ulaştığı ve özellikle pandemi döneminde birçok projenin yeniden hayat geçirildiği gözlenmektedir.

\section{Sonuç ve Tartışma:}

Bir kriz olarak aniden dünya genelindeki olumsuz etkileriyle gündeme gelen salgın süreci, özellikle ekonomik anlamda büyük darbelere yol açmıştır. Hükümetler kendi çaplarında bir takım önlemler alarak yurttaşlarının hayatta kalmaya devam etmesi amacıyla, özellikle özel girişimler şeklinde ticari varlıklarını sürdürmeye çalışan işletmeleri desteklemek için fon paketleri açıklamıştır. Bunun dışında yapılan proje destekleri ve toplantıların da ana gündemi salgında ekonomik direnci oluşturmaktır. Özellikle de pozitif ayrımcılık yaparak iş dünyasında bulunan kadın girişimcilerin desteklenmesi amacıyla yıllardır çalışmalar yapan TOBB, bu süreçte de aynı desteği sürdürmektedir. Girişimcilerin pandemi sürecinin yarattığı kriz ortamını firsata çevirerek, dijital ortamlarda iş yapma biçim ve yöntemlerinin teşvik edildiği projeler ekonomik kalkınma için son derece önemlidir. Proje içerikleri, amaçları ve çıktıları bağlamında değerlendirildiğinde, bu sürece uyumu kolaylaştırmaya yönelik projeler olduğu dikkati çekmektedir. Dijital uyumun artırılması, ekonomik anlamda yeniden canlanma ve toparlanma için kritiktir. Dünya genelinde tüm insanların internet kullanım oranlarındaki artış da dikkate alındığında, Covid-19 salgını da dahil tüm olağanüstü durumlarda, ekonomik zararların minimuma düşürülmesi için uyumun sağlanmasının gerekliliğinin bir göstergesidir. Özellikle özel sektör bağlamında hem ulusal hem de uluslararası birçok kurumsal işletme, pandemi sonrası çalışma prensiplerinin "dijital" platformlarda devam edeceğine dair açıklamalar yapmıştır. Bu bağlamda, yeni normalin çevrim içi ortamlarda ve yapay zeka, veri madenciliği gibi sektörlerde, gelecek inşa ettiği aşikardır. Tüm dünyada ekonomik bir krizin yaşanmasına sebep olan pandemi, iş yapma biçimlerini değiştirmekle kalmamış, birçok sektörü yok olma tehlikesi ile karşı karşıya bırakmıştır. Örneğin, ofis çalışanları açısından iş yeri kavramı bundan böyle "home office" şeklinde yaşadıkları evler olacaktır. Uzun bir süre kalabalık ortamlara sahip olan alış veriş merkezleri, sinemalar, gösteri ve konser salonları başta olmak üzere birçok işletme daha az ziyaretçi alabilecek ve ekonomik toparlanmaları da zaman alacak gibi gözükmektedir. Tüm bu sebeplerle, Türkiye örnekleminde ele aldığımız bir sivil toplum kuruluşu olan Türkiye Odalar ve Borsalar Birliğinin çalışmalarının dijitale uyumlaştırılmasındaki hız son derece dikkat çekicidir. Ayrıca, 26 Şubat 2021 tarihi itibariyle düzenledikleri sanal fuar etkinliği de dijitalleşmenin iş hayatına, Covid-19 sayesinde beklenen süreden daha hızlı sirayet etmesini sağlamıştır. Bu hız birçok kitle iletişim aracı tarafından 5,5 sene şeklinde telaffuz edilmektedir. Yani, gelecekte beklenen dijitalleşme hızı pandemi olmasa idi, bu kadar sene sonra zaten gerçekleşekti. Bu bağlamda, krizin altında yatan firsatları görmek ve değerlendirmek açısından, dijitalleşmenin önemine dikkat çekmeye çalışan bu çalışmada proje örneklerine yer verilmiştir. Gelecekte yapılacak çalışmalara örnek teşkil etmesi açısından içerikleri ve amaçları düzeyinde incelenen bu projelerin dijitale taşınması ile de başarısının arttığı dikkati çekmektedir. 


\section{INTRODUCTION}

The establishment of the new world order is possible with a number of radical changes in human lives. When we examine the revolutions that took places throughout history, we always come across some radical changes and breaking points. The discovery of wetlands at the beginning of human history and technological inventions in the formation of modern societies underlie these breaking points. People who discovered that the soil around wetlands was more fertile began to learn to trade when they gathered there and decided to live together. Meeting the needs such as eating and drinking, which are necessary to maintain the life cycle at a minimum level and are the basis of Abraham Maslow's hierarchy of needs, constitute the basis of trade. Throughout history, people who tried to meet their needs by trading the wheat they grew with the barley grown by someone else, have always struggled to survive. In the modern societies of the 21 st century, the main struggle of people is to survive because, throughout the history of humanity, the world has never been a rose garden, various disasters, pandemics and other difficulties forced human beings to struggle.

Human beings, who have struggled to survive to meet their basic needs, have not been satisfied by finding food and have always assumed unlimited needs. When evaluated in the context of demands and needs, the balance between supply and demand at the point where mass production has reached today is extremely striking. Modern marketing approach does not stop at the point of needing a product or service to be sold to people, it aims to reach people by creating a need because the struggle of people who make purchasing behaviors with their unlimited desires and needs for survival has also undergone formal changes. Furthermore, modern marketing approach explains the influence and guiding power of human behavior on commercial life depending on the changes in the preferences explained with the concept of "popular culture" in modern societies. Erdogan (2004: 4) explains that "popular culture supports, justifies and helps to sustain dominant social and economic relations. It is one of the concrete forms of mass culture, which is an expression of the economic, political and cognitive nature of the massproducing market. Mass culture refers to a culture of monopoly capitalism that sells both goods and images, shaped and changed according to the changes and needs of the international market, made in advance, pre-cut, packaged and presented." As one of the important indicators of popular culture, in other words, consumption culture, we come across rapidly developing virtual networks and how the human preferences related to these networks change rapidly and how quickly this change prepares the ground for different innovations.

This study draws attention to the necessity of transferring business methods to virtual environments in the digitalized world conditions as a result of the pressure created by the new COVID-19 pandemic on the economy. Social networks and internet technologies, which have shaped human life for the last 15 years, have necessitated to increase the integration of trade in this field due to the constraints experienced during the pandemic. Studies and projects the Union of Chambers and Commodity Exchanges of Turkey, which is an important nongovernmental organization in the field of trade and economy in Turkey, have revealed the necessity of digitalization of the business world.

\section{CONCEPTUAL FRAMEWORK}

The related literature offers many definitions of pandemic disease. However, in the literature, pandemic disease usually refers to high risk of transmission of infections. The dictionary of the Turkish Language Association defines pandemic as "pandemic disease which infects a large part of the surrounding people, animals or plants in a short time" and "the spread of a disease or another condition and its transmission to many people, epidemic" (TDK, 2020). Hekimoğlu (2019: 77) states that the Turkish equivalents of the words epidemic and pandemic are close to each other but not identical, and the distinction between the concepts of epidemic and pandemic is striking. Figure 1 below clearly demonstrates the distinction. 


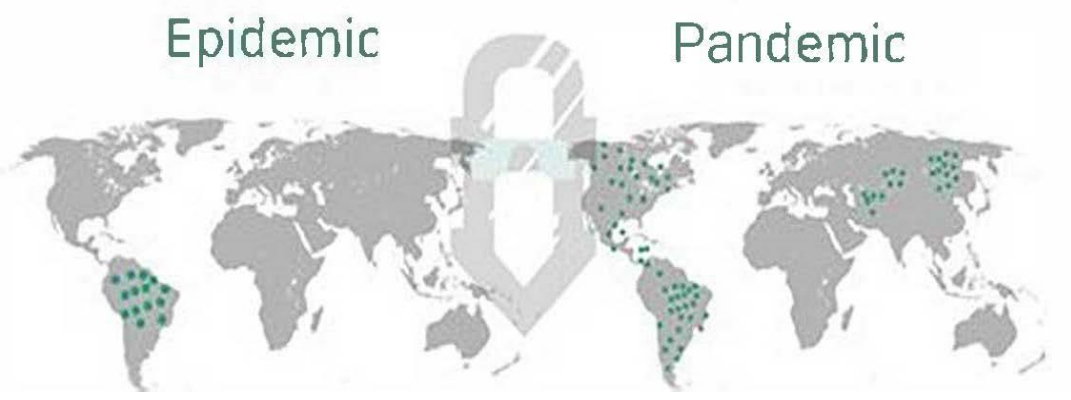

Figure 1. Difference between Epidemic and Pandemic

Source: (Veri Analiz, 2020).

Epidemic is used for a disease that infects people in a country or region, but pandemic is used for a disease that infects people all over the world. For example, a tragic epidemic outbroke in Seattle in January 1993, and within about three days, 400 people, most of whom were children, were affected by the severe infection caused by Escherichia coli, which was traced to contaminated and undercooked hamburgers (Büken, 2010: 63) while the COVID-19 pandemic affected people from all countries of the world and all demographic groups. In addition to the definitions made from the health dimension in the relevant literature, in the social dimension, Çakar (2015: 91) defines "pandemic" as a problem that requires urgent social and political measures and can create a crisis in the society.

Social definition of the concept of pandemic draws our attention to the fact that it is a situation that requires urgent action and it creates the concepts of social crisis. The concept of crisis is generally defined as sudden and unexpected situations. Aktan and Şen (2001:2) have stated that to evaluate any situation as a crisis, it should have the following basic elements:

Crises are the results of some unforeseen or unpredictable developments that will seriously affect the state at the macro level and the firms at the micro level. Calling negative developments that occur suddenly and unexpectedly crises is correct. Otherwise, every problem that occurs within the normal process does not mean a crisis. The crisis should be considered as a "serious problem" that unexpectedly appears. Routine developments and problems are not crises.

The most important feature of a crisis is that it occurs at an unpredictable or unforeseen moment.

Another important feature of the crisis is that it poses both a danger and a threat to individuals and organizations, and it creates new opportunities. In this sense, crisis is not a completely 'negative' concept as it is generally thought.

Crises can be short or long lasting. The short or long duration of the effects of crises on organizations depends on whether the organization takes the measures that can counter the crisis on time and applies them.

Finally, another characteristic of crises is that they have a contagious effect like an infectious disease. A crisis that occurs in any organization can affect other sectors, or a crisis in an organization can spread to other organizations that are in contact with this organization.

When the above-mentioned factors are evaluated together, rapid developments in environmental factors in the global competitive environment may cause businesses to face situations that can be called crisis (Erol, 2010: 165), however, it is not correct to call every negative situation a crisis. Although there are examples where some negative situations are evaluated as problems and resolved, as stated in the factors listed above, the widespread impacts of crisis situations are remarkable. When the widespread impact of COVID-19 around the world as of 2020 is evaluated, it is obvious that COVID-19 has created a crisis effect in many areas. In this process that is experienced as a global crisis, as Alptekin (2009: 9) has stated, all economies are affected from different aspects, and since the crisis is a chaos, some will lose while some will win in this chaos (Turan, 2011: 57). However, the COVID-19 pandemic has created such a crisis environment around the world that all countries are struggling with equal challenges, at least until a solution such as a vaccine is found. In this sense, making a correct diagnosis of the cause of the world economic crisis is necessary to find a way out of the crisis and to offer solutions (Akgüç, 2009: 6), and this diagnosis is of a nature that concerns every field from health to economics. Almost none of the epidemic 
diseases experienced in various periods throughout human history has not been prevalent worldwide in the form of a pandemic. Undoubtedly, the role of international circulation in the spreading effect of the pandemic experienced in this period is extremely high. As Kutlu and Demirci (2011: 132) state, the global economy and national economies regularly experience financial crises at short intervals, but the destructive effects of any of them have not been as high as the effects of COVID-19.

New behaviors such as social distancing, wearing masks, hygiene, not going out on the streets and avoiding collective organizations, which are the main measures taken by governments within the scope of combating the pandemic, have formed the basis of the new order both for individuals and institutions and laid the groundwork for many changes and innovations. Özatay and Sak (2020: 1) argue that these measures, which require the obligation to stay at home, which is among these measures, cause negative economic consequences. Many sectors, especially tourism, have been adversely affected by the prohibition or restriction of international or national circulation together with our current consumption habits. As Soylu (2020: 169) has stated, the fact that the pandemic has economic and social and dimensions, a composition of supply and demand shocks, and affects many behaviors of individuals, especially consumption behaviors, positions COVID-19 separately from other external shocks and crises. The biggest change that this pandemic process has made on individual behavior is experienced in the increase in the consumption of internet-based technologies. The number of digital applications is increasing day by day in many compulsory fields for the continuation of the life cycle, especially in the field of education. The transition to distance education with the closure of the school at all levels of education has made it compulsory for all people, including very young age groups, to use computers and internet connections. The concept of remote working has also developed for employees who face restrictions not only at school but also at the point of going to workplaces and adopt the flexible working principle. The use of a number of applications for conducting all meetings over online platforms has increased enormously. Almost all sector employees, except the production sector, have to work remotely within the scope of the measures. All these situations have increased the use of digital technologies and enabled the transfer of information through these platforms. Thanks to these information technologies, making predictions and using these technologies at the point of decision-making have become very important during the pandemic process (Karanfiloğlu and Kara, 2020: 91), which has triggered the widespread use of these technological devices. In fact, Deniz's (2020) study has revealed that the individuals who have left the house very little due to social and physical isolation rules during the pandemic have started to hold online concerts on Instagram to support each other psychologically (Deniz, 2020: 199), which proves the integration of technology in many areas.

The biggest effects of the pandemic, which necessitates the transition to a new normal order which is quite different from the old normal order, undoubtedly manifests itself in the trading institutions. There have been many negative situations such as places that have been closed due to the measures (restaurants, cafes, wedding halls, entertainment venues, shopping centers, etc.), businesses that have financial difficulties due to curfews and are in bankruptcy and these businesses continue to experience these situations due to the uncertainty of the pandemic process. Consumption continues at the same pace, although production in terms of business is reduced to a minimum. Therefore, businesses whose infrastructure and business area are suitable for digital have quickly turned into ecommerce format. Since the new normal will create a business area in which these transitions will be experienced more, training and development activities related to e-commerce and digital platforms will be an important investment area for businesses.

\subsection{The New Covid-19 Pandemic}

COVID-19 has begun to be recognized worldwide as of December 2019 and has begun to be seen in Turkey as of March 2020, its effects have quickly turned into a global crisis. As the latest threat to global health, the COVID19 outbreak has progressed as an ongoing pandemic of respiratory disease called Coronavirus Disease 2019 (Fauci, Lane and Redfield, 2020). COVID-19, which is an emerging respiratory disease caused by severe acute respiratory syndrome coronavirus 2 (SARS-CoV-2) (Cao, 2020: 269), is a global threat, and its alarming effects on individual and collective health, and emotional and social functioning are increasing day by day (Pfefferbaum and North, 2020). Due to its rapid spread among people and its contagious nature, it has affected people's lives and has significantly restricted their movements both socially and psychologically. Furthermore, the pandemic has profoundly changed people's normal routines, and all of these negativities have taken place in a very short time (Helmich and Bloem, 2020: 351) and have a serious negative impact. COVID-19 has also caused the entire routine life cycle, especially health systems (Cucinotta and Vanelli, 2020: 157), to change in a short period of almost one year. Therefore, at the very beginning of the process, on January 30, 2020, the World Health Organization 
Emergency Committee declared a global health emergency based on increasing case reporting rates in China and all international locations (Velavan and Meyer, 2020: 278) and called for a series of measures to be taken. The uncertainty of its effect on the global economy, especially on the Chinese economy (McKibbin and Fernando, 2020: 45), continues to have dramatic effects.

The uncertainties experienced in the process and the impossibility of predictability of the results not only threaten the physical health of people, but also affect people's mental health, especially in emotional and cognitive terms. The root cause of these impacts is assessed in the context of economic difficulties because no previous infectious disease epidemic, including the Spanish Flu, has affected the stock market as strongly as the COVID-19 outbreak (Baker, 2020). Although many countries have informed the world about their works on developing antiviral drugs or vaccines to control COVID-19, a medically approved treatment has yet to be found. Therefore, the entire world population is currently struggling with dramatic difficulties in all areas (social, environmental, health and economic) due to the impact of the pandemic. In this regard, the affected countries try to slow down the transmission of the virus with a number of measures such as the social distancing, closing some businesses, increasing the number of tests and treatments, and restricting crowded and large meetings. These measures taken to stop the spread of the COVID-19 virus, especially the social distancing, cause the financial markets, company offices, businesses and activities to close down, paving the way for economic negativities. Moreover, the uncertainty regarding the process causes a serious contraction for consumers, investors and international trade.

Studies on the subject and the announced government policies have not been in the form of applications that businesses can easily implement to provide rapid protection from the negative effects of the pandemic. Bartik et al. (2020) conducted a study with more than 5.,800 small businesses to examine the effects of COVID-19 on them. Their study revealed striking results. The first result was the increasing unemployment rates as a result of massive layoffs. The second was the economic difficulties caused by the closure of many enterprises. Another result was that many small businesses had experienced negative consequences in terms of cash flows during the pandemic due to the fragile nature of small businesses. In this regard, small businesses applied for funding which was provided by the government through the Coronavirus Aid, Relief, and Economic Security Act. However many of them faced problems such as bureaucratic problems while accessing the funding program, the low acceptance rates for loans compared to grantsbased programs, and the negative effects of job flexibility (Bartik et al., 2020: 17656). In addition, Seetharaman (2020) stated that the first effects of the pandemy on the economy were due to sudden decreases in both total demand and supply. Widespread closure of businesses to control the pandemic caused a decrease in total supply, and the decrease in consumption and investment also caused a decrease in demand as well (Seetharaman, 2020: 3 ).

When evaluated in general, the pandemic is not the only reason that causes negative effects on the economies of the world, there are bigger problems in the world. However, while poverty kills the poor, war threatens a certain region, the COVID-19 virus can kill any person from any socio-economic status anywhere in the world and poses serious threats to economies considered to be the strongest. In other words, the pandemic makes the struggle of all humanity and the possibility of survival equal.

However, the economic measures implemented in the context of the abovementioned equality principle require a positive discrimination for women in business life, as can be understood from the contents of the projects, which are the main discussion of this study. However, the economic measures implemented in the context of the abovementioned equality principle require a positive discrimination for women in business life, as can be understood from the contents of the projects, which are the main discussion of this study.

Alon et al. stated that the economic downturn caused by the current COVID-19 outbreak had significant implications for gender equality both during the downturn and the subsequent recovery periods. Compared to the "regular" recessions that affect men's employment more severely than women's employment, their study explained that the employment decline due to social distance measures had a great impact on sectors where the share of female employment was high. In addition, they found that closures of schools and day care centers had an undeniable effect on the increasing female unemployment rates, as childcare needs had increased substantially and this had a particularly large impact on working mothers. They stated that the effects of the crisis on working mothers were likely to be permanent due to the high returns from experience in the labor market. They underlined the importance of ensuring the presence of women in business with opposing forces that could ultimately promote gender equality in the labor market (Alon, Doepke, Olmstead-Rumsey and Tertilt, 2020). In this regard, projects that have been implemented by the Union of Chambers and Commodity Exchanges of Turkey to encourage increasing the digital integration of women whose jobs are negatively impacted are of vital importance. 


\section{METHOD}

The current study evaluated the projects to encourage digitalization of businesses due to the COVID-19 pandemic, which negatively affected human life, especially due to its negative economic consequences, and interrupted the commercial processes of many businesses in the global crisis environment. This study employed content analysis method, one of the qualitative research methods, to evaluate eight projects conducted by the Union of Chambers and Commodity Exchanges of Turkey. This study, which was designed in the form of evaluative analysis, which is one of the content analysis methods, presented a framework on the purpose, target audience and outputs of the projects based on the evidence that routine businesses could also be done online, especially with the closure of businesses, which was one of the economic difficulties during the pandemic, and the transition to digital environments. Since the transformation into e-commerce is one of the important combat tools against the pandemic within the scope of these projects, which are especially important for women entrepreneurs, this study makes a significant contribution to the literature.

\subsection{Data Collection and Analysis}

The data were obtained through the Union of Chambers and Commodity Exchanges of Turkey's website. Some private information about the relevant data and project contents was obtained after the correspondence with the relevant institution and used within the scope of this study after obtaining the necessary permissions. Although the researcher tried to reach out the certain demographic information, including gender, about the entrepreneurs in Turkey, the related organizations stated that there was no clear set of data to share. The study analyzed the details of the project prepared and implemented on digitalization, which started in the past and continued during the pandemic, using content analysis.

\subsection{Findings}

The information that the Union of Chambers and Commodity Exchanges of Turkey shares states that the quota of the Women Entrepreneurs Council is limited to the number of council members of the Chamber and Exchange in each province. Therefore, although the Union of Chambers and Commodity Exchanges of Turkey has nearly 7,000 women entrepreneur members, this number does not reflect the overall profile of Turkey. The current study determined that there were many projects organized by the institution for a number of purposes such as increasing the digital adaptation of all women in the country, especially women entrepreneurs, and supporting their developments. Content analysis for these projects is given in the table below. The study made a three-dimensional evaluation, namely, project target audience, aim, and outputs. The results are given in the table below. The results indicated that the relevant projects achieved their purpose and many projects were revived, especially during the pandemic.

Table 1. Projects and Their Contents

\begin{tabular}{|c|c|c|c|}
\hline Name of the Project* & Target Group & Purpose & Outputs \\
\hline $\begin{array}{l}\text { Woman Writing the } \\
\text { Future-in cooperation } \\
\text { with Turkcell** }\end{array}$ & $\begin{array}{l}\text { Women } \\
\text { entrepreneurs: } \\
\text { Approximately } \\
3,000 \text { women } \\
\text { applied to the } \\
\text { project. More } \\
\text { than } 1500 \\
\text { women have } \\
\text { completed all } \\
\text { training from } \\
\text { beginner } \\
\text { advanced. }\end{array}$ & $\begin{array}{l}\text { Women Writing the Future Project was first launched in } \\
\text { cooperation by the Union of Chambers and Commodity } \\
\text { Exchanges of Turkey (TOBB), Turkcell and TOBB } \\
\text { Women Entrepreneurs Council in } 18 \text { provinces in } 2017 \text {. } \\
\text { The project aimed to educate women about software, to } \\
\text { increase women's employment capacity and } \\
\text { entrepreneurship in the field of technology. } \\
\text { "Women Writing the Future", which received the } \\
\text { "Technology Sector Leadership for Women" award within } \\
\text { the scope of GSMA Global Mobile Awards held in } \\
\text { Barcelona, was cited as an exemplary project in the Women's } \\
\text { Empowerment Principles (WEPs) event organized by the } \\
\text { United Nations Entity for Gender Equality and the } \\
\text { Empowerment of Women (UN Women) to advance gender } \\
\text { equality and enable women to benefit from future } \\
\text { opportunities (Gelecegi Yazanlar, 2020). }\end{array}$ & $\begin{array}{l}3000 \text { participants } \\
\text { Approximately } 500 \text { projects } \\
\text { TOBB and Turkcell carried out Women } \\
\text { Writing the Future Project to support } \\
\text { women who wanted to work in the } \\
\text { mobile technology industry or realize } \\
\text { their business idea using mobile } \\
\text { technologies, to develop mobile } \\
\text { applications, and to increase women's } \\
\text { employment capacity and } \\
\text { entrepreneurship in this field. The } \\
\text { project, which was first implemented in } \\
18 \text { provinces in } 2017 \text {, was revived in } 24 \\
\text { provinces in } 2019 \text { to meet intense } \\
\text { demands. The trainings within the scope } \\
\text { of Women Writing the Future Project } \\
\text { started simultaneously in } 58 \text { classrooms } \\
\text { with } 1601 \text { participants in } 24 \text { provinces on } \\
16 \text { March 2019. Finals and award } \\
\text { ceremony were held on November } 23 \text {, } \\
2019 \text {. }\end{array}$ \\
\hline
\end{tabular}




\begin{tabular}{llll}
\hline Name of the Project* & Target Group & Purpose & Outputs
\end{tabular}

Turkey Technology Entrepreneurs The main sponsors of TOBB Turkey Technology Meetings 96,000 SMEs at 71 conferences in 61

Meetings - in were Akbank and Vodafone. The organization partners were provinces:

cooperation with EticaretSEM, Ticaret Merkezi, Trendyol, IdeaSoft, OPLOG, Under the leadership of the Union of

Vodafone and Akbank iPara, ePttAVM, İninal, Dijital Yol, Tek Kılavuz and Ajanstr Chambers and Commodity Exchanges (Türkiye Tekonolji Buluşmaları, 2020).

of Turkey, we increase the awareness of SMEs on digitalization and lead their digital transformation. Until today, we have reached more than 97,800 SMEs in 76 conferences in 32 provinces.

One Click Europe** Entrepreneurs $\quad$ OneClickEurope is a training program that will support 1400 participants in 10 provinces
Turkish companies to e-export to all EU countries in 5 languages through AmazonThe training seminars were held in Turkey in TOBB's trade and industry chambers, were given by Bogazici University Lifelong Learning Center instructors and Amazon teams. Educational seminars, which covered topics such as the potential of e-export, steps required to export through Amazon, opportunities Amazon offers to sellers, took place in 20 provinces in Turkey during the 2019-2020 period. The training program aims to guide companies on their way to e-export to Europe from beginning to end and still continues (Bi Tikla Avrupa, 2020).

Cross-Border SMEs - Women in cooperation with Entrepreneurs Facebook and Habitat
The project was carried out in cooperation with TOBB,

Facebook and Habitat. Within the scope of the project, Facebook opened a center called Facebook Station in Istanbul in 2019 in cooperation with TOBB and Habitat to expand its investment in Turkey. The project was not limited to Istanbul, but also local hubs were opened in Anatolia. Within the scope of the project, Facebook aimed to create an awareness to support SMEs to grow, digitalize and cross borders using Facebook Family of apps (Habitat, 2020).

Boost with Facebook Entrepreneurs Within the scope of Boost with Facebook project, entrepreneurs were trained on digital marketing to grow their businesses and connect with their target audiences. A total of 20,000 people were targeted in 20 provinces (Boost with Facebook, 2020).

Facebook Station - in Entrepreneurs Facebook Station is the first community hub, which was Satellite centers opened in Denizli,

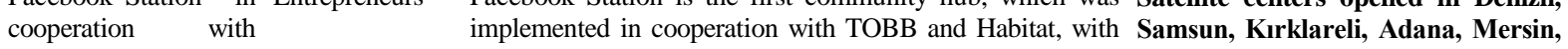
Habitat Facebook's missons to empower people to build Ankara, Trabzon, Bursa, Van, communities and to make the world closer together Diyarbakır. (Facebook İstasyon, 2020).

My Sister Project - in Women
cooperation with Entrepreneurs
$\begin{aligned} & \text { CocaCola, ITTÜ and } \\ & \text { Habitat ** }\end{aligned}$

Under the leadership of TOBB, My Sister project was carried In 2018, 9300 women received out to strengthen the economic position of women in finance, informatics, communication cooperation with the Habitat Association, Coca-Cola Turkey and entrepreneurship training in 30 and Istanbul Technical University. $\quad$ provinces. In 2020, the project aims The COVID-19 pandemic, which affected the world, deeply to reach 100 thousand women in 81 affected the food and beverage sector, as it affected all sectors. provinces:

Businesses in the food and beverage sector, especially those The project was carried out in 40 with small business status, are expected to face great risks that provinces in 2018-2019. The project will cease their activities in this period. My Sister Project aims reached more than 18,000 women to support 30 entrepreneur women in the food and beverage through finance, informatics, sector, which will be selected from 81 provinces, to promote communication and entrepreneurship the flavors they produce, to highlight visibility activities and to training. In addition, mobile training contribute to strengthening their socio-economic position. truck that set off as of 2018 reached The project aims to support entrepreneur women working in more than 1,700 women.

the food and beverage sector by giving business development Organized for the first time in 2019, My grants of 25 thousand TL for 29 entrepreneur women and 40 Sister Project Local Flavors Grant thousand TL for one entrepreneur woman so that they can Program provided a grant of 275,000 develop their businesses.

TL to 11 entrepreneur women from 30 My Sister Grant Program Camp will help women working in provinces to support their business the food and beverage sector to develop their businesses and development processes on food provide them with branding support. In addition to revealing entrepreneurship.

their entrepreneurship stories, entrepreneurial women will be

supported through trainings at the end of the process $\left(\mathrm{K}_{1 \mathrm{Z}}\right.$ Kardeşim, 2020). 


\begin{tabular}{|c|c|c|c|}
\hline Name of the Project* & Target Group & Purpose & Outputs \\
\hline $\begin{array}{l}\text { Life is Simpler with } \\
\text { the Internet (Life is } \\
\text { Simpler with the } \\
\text { Internet for Women } \\
\text { with Target Project) }\end{array}$ & Entrepreneurs & $\begin{array}{l}\text { Digital Literacy, Digital Marketing, Design Thinking } \\
\text { Workshop: } \\
\text { The project was implemented to make information } \\
\text { technologies accessible to everyone, which is the main } \\
\text { driving force for sustainable social development and } \\
\text { economic growth, in cooperation with TOBB, United } \\
\text { Nations Development Programme (UNDP), the Habitat } \\
\text { Association and Turk Telekom Group. } \\
\text { Based on the fact that active participation and employment } \\
\text { of women in the economy is one of the basic elements of } \\
\text { sustainable development, the project aimed to contribute to } \\
\text { the goals of ensuring continuity in economic growth, social } \\
\text { development and full realization of social justice in the new } \\
\text { period. In the new period, the project aimed to reach a total } \\
\text { of 5,000 women through digital literacy, digital marketing } \\
\text { and design thinking workshops for women over } 18 \text { who were } \\
\text { entrepreneurs or had entrepreneurial motivation (Habitat } \\
\text { Kadin, 2020). }\end{array}$ & Training for 46 thousand people \\
\hline
\end{tabular}

* The data was organized in the light of the information contained in the e-mail upon the request of TOBB (2020) Entrepreneurship Directorate on 04.12.2020. In addition, the data was enriched with the data of the European Union Desk in Sivas Chamber of Commerce and Trade.

** Projects that have been revived in a virtual environment as of May 2020 during the pandemic and are currently ongoing.

\section{CONCLUSION}

The pandemic, which suddenly came to the fore as a crisis with its negative effects around the world, caused major economic damage. Governments have taken a number of measures to ensure the survival of their citizens and have announced packages of funds to support businesses, especially private enterprises, seeking to maintain their commercial existence. In addition, the main agenda of the project supports and meetings is to create economic resistance in the pandemic. TOBB, which has been working for years to support women entrepreneurs in the business world by making positive discrimination, continues the same support in this process. Projects, which encourage entrepreneurs to do business in digital environments by turning the crisis environment, which is created by the pandemic, into an opportunity, are extremely important for economic development. When the projects are evaluated in the context of their contents, objectives and outputs, projects that facilitate adaptation to the pandemic draw attention.

This process, especially in which the length of staying at home is extended and many important issues, including education, are transferred to digital environments, has created an inevitable necessity for commercial life. Projects that include strategies to fully or partially move all commercial activities, except for production, to digital, and survive with less loss and damage hold great importance. The number of similar projects should continue to increase.

Increasing digital adaptation is critical to economic revival and recovery. The increase in internet usage rates of all people around the world is an indication of the need to adapt the era to minimize economic losses in all extraordinary situations, including the COVID-19 outbreak. Especially in the context of the private sector, many national and international corporate enterprises have made statements that their working principles after the pandemic will continue on "digital" platforms. In this context, it is clear that the new normal is building a future in online environments and industries such as artificial intelligence and data mining. The pandemic, which caused an economic crisis all over the world, not only changed the way of doing business, but also exposed many sectors to the danger of extinction. For example, for office workers, the concept of workplace will now be the houses they live in as "home offices". Many businesses, especially shopping malls, cinemas, show and concert halls, which had crowded environments for a long time, will receive fewer visitors and their economic recovery will take time.

For these reasons, the current study has examined the projects of the Union of Chambers and Commodity Exchanges of Turkey, which is a non-governmental organization in Turkey, and has found that the organization has implemented many of its projects into a digital environment extremely fast. In addition, the virtual fair event they organized as of February 26, 2021 enabled digitalization to spread to business life faster than expected. Many mass media have expected this speed to be five and a half years. In other words, the expected speed of digitalization in the future would have happened after five and a half years, if it were not for the pandemic. In this context, this 
Süleyman Demirel Üniversitesi Vizyoner Dergisi, Yıl: 2021, Cilt: 12, Sayı: 31, 701-711.

Süleyman Demirel University Visionary Journal, Year: 2021, Volume: 12, No: 31, 701-711.

study, which tried to draw attention to the importance of digitalization in terms of seeing and evaluating the opportunities underlying the crisis, included examples of projects. It is noteworthy that the success of these projects, which are examined at the levels of their contents and purposes in terms of setting examples for future studies, has increased with their transfers to digital.

In this study, the importance of projects for women entrepreneurs has been highlighted. Important and good results that emerge when entrepreneurship is supported draw attention. The importance of the projects carried out in the world in terms of education and development is striking. With these projects carried out in Turkey, support for women entrepreneurship is increasing.

\section{DECLARATION OF THE AUTHOR}

Declaration of Contribution Rate: The author contributes the study on his/her own.

Declaration of Support and Thanksgiving: No support is taken from any institution or organisation.

Declaration of Conflict: There is no potential conflict of interest in the study.

\section{REFERENCES}

Akgüç, Ö. (2009). Kriz nedeni ve çıkış yolları. Muhasebe ve Finansman Dergisi, 42, 6-11.

Aktan, C. C. and Şen, H. (2001). Ekonomik kriz: nedenler ve çözüm önerileri. Yeni Türkiye Dergisi, 2(42), 1.

Alon, T. M., Doepke, M., Olmstead-Rumsey, J. and Tertilt, M. (2020). The impact of COVID-19 on gender equality (No. w26947). National Bureau of Economic Research.

Alptekin, E. (2009). Küresel krizin Türkiye ekonomisi ile sanayisine yansımaları ve dipten en az zararla çıkış yollar1. AR\&GE Bülten, 5-12.

Baker, S. R., Bloom, N., Davis, S. J., Kost, K. J., Sammon, M. C. and Viratyosin, T. (2020). The unprecedented stock market impact of COVID-19 (w26945). National Bureau of Economic Research.

Bartik, A. W., Bertrand, M., Cullen, Z., Glaeser, E. L., Luca, M. and Stanton, C. (2020). The impact of COVID19 on small business outcomes and expectations. Proceedings of the National Academy of Sciences, 117(30), 17656-17666.

Bi Tikla Avrupa. (2020). Accessesible information. Access address: https://bitiklaavrupa.com/, (04.12.2020).

Boost with Facebook. (2020). Accessesible information. Access address: https://www.hackquarters.co/bwf, (04.12.2020).

Büken, N. Ö. (2010). Pandemik influenza ve etik. Hacettepe Tıp Dergisi, 41, 62-68.

Çakar, B. (2015). Avrupa ve ABD'de artan salgın: Nefret suçu. The Global a Journal of Policy and Strategy, 1(2), 91-113.

Cao, X. (2020). COVID-19: immunopathology and its implications for therapy. Nature Reviews Immunology, 20(5), 269-270.

Cucinotta, D. and Vanelli, M. (2020). WHO declares COVID-19 a pandemic. Acta Bio Medica: Atenei Parmensis, 91(1), 157.

Deniz, A. K. (2020). Covıd-19 salgını sürecinde dijitalleşen eğlence anlayışı: çevrim içi konserler. Stratejik ve Sosyal Araştırmalar Dergisi, 4(2), 191-206.

Erdoğan, İ. (2004). Popüler kültürün ne olduğu üzerine. Bilim ve Aklın Aydınlı̆̆ında Ĕgitim Dergisi, 5(57), 7-19.

Erol, M. (2010). Ekonomik kriz ve KOBİ’ler. Girişimcilik ve Kalkınma Dergisi, 5(1).

Facebook İstasyon. (2020). Accessesible information. Access address: https://istasyon.fb.com/tr/, (04.12.2020).

Fauci, A. S., Lane, H. C. and Redfield, R. R. (2020). Covid-19-navigating the uncharted. Access address: https://www.nejm.org/doi/full/10.1056/nejme2002387, (21.11.2020). 
Süleyman Demirel Üniversitesi Vizyoner Dergisi, Yıl: 2021, Cilt: 12, Sayı: 31, 701-711.

Süleyman Demirel University Visionary Journal, Year: 2021, Volume: 12, No: 31, 701-711.

Geleceği Yazanlar. (2020). Access address: https://gelecegiyazanlar.turkcell.com.tr/gelecegiyazankadinlar, (04.12.2020).

Habitat Kadın. (2020). Access address: https://habitatdernegi.org/girisimcilik/hedefi-olan-kadina-internetle-hayatkolay/, (04.12.2020).

Habitat. (2020). Access address: https://habitatdernegi.org/blog/sinirlari-asan-kobiler-egitim-programi/, (04.12.2020).

Hekimoğlu, C. H. (2019). Sağlık hizmeti ilişkili enfeksiyon salgınlarının iİncelenmesi. BUHASDER Kongresi 8. Tepecik Enfeksiyon Günleri.

Helmich, R. C. and Bloem, B. R. (2020). The impact of the COVID-19 pandemic on Parkinson's disease: Hidden sorrows and emerging opportunities. Journal of Parkinson's disease, 10(2), 351.

Karanfiloğlu, M. and Kara, N. (2020) İletişimin dijitalleşmesi: Pandemi (COVID-19) ve enformasyon teknolojileri. AJIT-e: Bilişim Teknolojileri Online Dergisi, 11(42), 87-99.

Kız Kardeşim. (2020). Access address: https://kizkardesim.net/, (04.12.2020).

Kutlu, H. A. and Demirci, N. S. (2011). Küresel finansal krizi (2007-?) ortaya çıkaran nedenler, krizin etkileri, krizden kısmi çıkış ve mevcut durum. Muhasebe ve Finansman Dergisi, (52), 121-136.

McKibbin, W. J. and Fernando, R. (2020). The global macroeconomic impacts of COVID-19: Seven scenarios. Centre for Applied Macroeconomic Analysis (CAMA) Working Paper No. 19/45.

Özatay, F. and Sak, G. (2020). COVID-19'un Ekonomik sonuçlarını yönetebilmek için ne yapılabilir?. TEPAV Politika Notu, (202005).

Pfefferbaum, B. and North, C. S. (2020). Mental health and the Covid-19 pandemic. New England Journal of Medicine, Access address: https://www.nejm.org/doi/full/10.1056/NEJMp2008017, (21.11.2020).

Seetharaman, P. (2020). Business models shifts: Impact of Covid-19. International Journal of Information Management, 54, 102173.

Soylu, Ö. B. (2020). Türkiye ekonomisinde COVID-19'un sektörel etkileri. Avrasya Sosyal ve Ekonomi Araştırmaları Dergisi, 7(6), 169-185.

TDK. (2020). Access address: https://sozluk.gov.tr/, (19.11.2020).

TOBB. (2020). Girişimcilik Müdürlüğü. Access address: https://www.tobb.org.tr/Girisimcilik/Sayfalar/AnaSayfa.php , (22.11.2020).

Turan, Z. (2011). Dünyadaki ve Türkiye'deki krizlerin ortaya çıkış nedenleri ve ekonomik kalkınmaya etkisi. Niğde Üniversitesi İ̈BF Dergisi, 4(1), 56-80.

Türkiye Tekonolji Buluşmaları. (2020). Access address: https://www.teknolojibulusmalari.com/, (04.12.2020).

Velavan, T. P. and Meyer, C. G. (2020). The COVID-19 epidemic. Tropical Medicine and International Health, 25(3), 278.

Veri Analiz. (2020). Access address: https://www.verianaliz.net/pandemi-tarihi-corona-covid19-veri-analizinfografik/, (21.11.2020). 